\title{
Vegetative and productive behavior of kiwifruit 'Elmwood' submitted to pruning with different bud loading levels
}

\author{
Francisco Antonello Marodin ${ }^{1}$, Paulo Vítor Dutra de Souza ${ }^{2}$, Samar Velho da Silveira ${ }^{3}$, \\ Leonardo Zucuni Guasso ${ }^{1}$, Marília Lazarotto ${ }^{2}$, Augusto Sassi ${ }^{4}$
}

\begin{abstract}
The objective of this study is to evaluate the vegetative and productive behavior of kiwifruit trees cv. 'Elmwood' submitted to different intensities of pruning, in "Serra Gaúcha" region. Treatments consisted in maintaining different bud load levels in each cane of 10, 15 and 20 buds cane ${ }^{-1}$. The experiment, carried out during the 2016/2017 vegetative season had a completely randomized design with nine repetitions per treatment. Bud fertility, vegetative, productive and fruit quality features were evaluated. The percentage of mixed buds was higher next to the cane apex in three different treatments, while in the base of each cane ocurred the highest percentage of non sprouting buds. The decrease in the number of buds per cane induced larger leaves and increased leaf dry matter. Longitudinal and transversal diameter of fruits and fruit mass were inversely proportional to the number of buds per cane. Pruning of 'Elmwood' kiwifruit tree with different number of buds did not influence the index of real bud fertility, but affected directly leaf and shoot size. Pruning maintaining canes with 10 buds favors the increase of fruit weight and did not reduce productivity.
\end{abstract}

Index terms: Actinidia deliciosa, kiwi, productivity.

\section{Comportamento vegetativo e produtivo de kiwizeiro 'EImwood' submetido a diferentes intensidades de poda}

Corresponding author: famarodin@hotmail.com

Received: June 12, 2018. Accepted: August 28, 2018

Copyright: All the contents of this journal, except where otherwise noted, is licensed under a Creative Commons Attribution License.

\section{(cc) $\mathbf{E Y}$}

\begin{abstract}
Resumo-O objetivo deste trabalho foi avaliar o comportamento vegetativo e produtivo de kiwizeiros da cultivar 'Elmwood' submetidos a diferentes intensidades de poda, na região da Serra Gaúcha. Os tratamentos utilizados consistiram na manutenção de diferentes níveis de cargas de gemas: 10; 15 e 20 gemas vara $^{-1}$. O delineamento experimental foi o inteiramente casualizado, com nove repetições por tratamento. O experimento foi realizado durante o ciclo 2016/2017, avaliando-se a fertilidade das gemas, os atributos vegetativos, os produtivos e os de qualidade dos frutos. $\mathrm{O}$ maior percentual de brotações mistas foi próximo ao ápice da vara, nos três diferentes tratamentos; já na base dos ramos de ano, ocorreu o maior percentual de gemas que não brotaram. A diminuição da carga de gemas por vara induziu aumento do tamanho das folhas e incremento da matéria seca foliar. O diâmetro longitudinal, transversal e a massa de fruto foram inversamente proporcionais ao número de gemas por vara. A poda de kiwizeiros 'Elmwood' com diferentes cargas de gemas não influencia o índice de fertilidade real das gemas, porém interfere diretamente no tamanho das folhas e dos ramos do ano. A poda, mantendo varas com 10 gemas, favorece o aumento da massa de fruto e não reduz a produtividade.
\end{abstract}

Termos para indexação: Actinidia deliciosa, kiwi, produtividade.

\footnotetext{
${ }^{1}$ Agronomist, Universidade Federal do Rio Grande do Sul (UFRGS) - MSc in Plant Science, Porto Alegre-RS, Brazil. E-mail: famarodin@ hotmail.com; leonardoguasso@yahoo.com.br.

${ }^{2}$ Professor, Dr., Universidade Federal do Rio Grande do Sul (UFRGS), Porto Alegre-RS, Brazil. E-mail: pvdsouza@ufrgs.br; marilia.lazarotto@ ufrgs.br.

${ }^{3}$ Researcher, Dr., Embrapa Uva e Vinho, Bento Gonçalves-RS, Brazil. E-mail: samar.velho@embrapa.br.

${ }^{4}$ Agronomy student, Universidade Federal do Rio Grande do Sul (UFRGS), Porto Alegre-RS, Brazil. Email: augustobsassi@hotmail.com
} 


\section{Introduction}

Kiwifruit is the $15^{\text {th }}$ most produced fruit in the world. World production in 2016 was 4.27 million tons in 277 thousand hectares (FAO, 2017). Brazil is not included in the list of the largest kiwifruit producers; however, it is a major importer and presents satisfactory soil and climatic conditions for its cultivation. According to Brasil (2017), between January and November 2017, Brazil imported 23.9 thousand tons of fresh kiwifruits, which represented US\$ 34.9 million. More than $90 \%$ of world kiwifruit production today is based on 48 cultivars and selections of two kiwifruit species: Actinidia deliciosa C.F. Liang et A.R. Ferguson and Actinidia chinensis Planch (ZHEN et al., 2004).

Among the phytotechnical managements used in the crop, several researches have reported that pruning is essential to obtain good fruit yields over the years. The bud load level after winter pruning is one of the most important factors, directly affecting yield and fruit characteristics (CANGI and ATALAY, 2006). In addition, for Wilson and Littler (1992), flowering and the final number of fruits by sprouting are influenced by the sprouting period and the cane bud position.

In kiwifruit crop, pruning is performed aiming to give the plant a certain shape in relation to the planting system used, to optimize production, to improve the action of pollinating insects (bees, mainly), to make phytosanitary treatments more efficient and to improve air circulation and light diffusion, allowing the regular development of fruits and the formation of mixed buds for the following year (CACIOPPO, 1989). Although it is a fundamental management practice for the crop, no studies on kiwifruit pruning for the growing conditions of southern Brazil have been found in literature.

Considering that experimental reports are scarce, the aim of this work was to evaluate the vegetative and productive behavior of kiwifruit trees 'Elmwood' cultivar submitted to different pruning intensities in the "Serra Gaúcha" region, Southern Brazil.

\section{Material and methods}

The experiment was conducted in the 2016/17 cycle in a commercial orchard at "Linha 47 " site, municipality of Farroupilha, $\left(29^{\circ} 08^{\prime} 58.6^{\prime \prime} \mathrm{S}\right.$ and $51^{\circ} 24^{\prime} 46.8^{\prime \prime} \mathrm{W}, 708$ $\mathrm{m}$ above sea level), with annual temperature, relative humidity and rainfall values of $17.2^{\circ} \mathrm{C}, 76 \%$ and 1736 mm, respectively (INMET, 2018). According to Köppen classification, the local climate is $\mathrm{Cfb}$, and the climatic results observed during the experiment are presented in Figure 1 (minimum and maximum air temperatures, rainfall and cold hours below $7.2^{\circ} \mathrm{C}$ ), obtained through meteorological station installed in the experimental area.
The soil at the experimental site is a Cambisol. The average number of cold hours $(\mathrm{CH})$ with temperatures lower $7^{\circ} \mathrm{C}$ is 464 between May and September (MATZENAUER et al., 2005). In the year 2016, the accumulation of temperatures below $7.2^{\circ} \mathrm{C}$, from May to September in the experimental area, was 612 hours.

'Elmwood' kiwifruit trees (Actinidia deliciosa) at the age of 13 years were used, grafted on plants derived from seeds of 'Bruno' variety fruits (A. deliciosa), conducted in a trellis system. Plants were spaced $2.5 \mathrm{~m}$ inside the row and $4.0 \mathrm{~m}$ between rows, following the east-west orientation, totaling 1,000 plants per hectare. The cultivar used as pollinator in the orchard was 'Matua' (A. deliciosa) at a ratio of 1: 8 .

The experimental design was completely randomized with nine replicates per treatment, observing uniformity, vigor and health of plants. Winter pruning was performed on June 14, 2016, with subsequent application of hydrogen cyanamide (Dormex ${ }^{\circledR}$, Basf Co., $520 \mathrm{~g} \mathrm{~L}^{-1}$ active ingredient) at dose of $4 \%$ of commercial product. No green pruning was performed during the 2016/17 cycle. All plants of the experiment were completely pruned in a mixed pruning, leaving 12 branches (canes), distant at least $30 \mathrm{~cm}$ between them and equally distributed by the plant. Treatments consisted in the maintenance of different bud load levels on each cane: 10, 15 and 20 buds cane $^{-1}$, which represented, respectively, 120, 180 and 240 buds originating from canes per plant. In all treatments, 15 spurs on average were left, with two buds each, per plant. The total plant load in the three different treatments was 150 , 210 and 270 buds, respectively.

Phenological determinations of budbreak and flowering stages were carried out in the proposed treatments. The beginning of budbreak was considered when at least $50 \%$ of buds reached the $9^{\text {th }}$ stage of the description proposed by Salinero et al. (2009), called the bud burst stage, when scales are separated and small green leaves are visible, still covered by brown trichomes. The end of budbreak was characterized when sprouting ceased. For the beginning of flowering, $10 \%$ of open flowers were considered and for the end of flowering when the beginning of fruiting was already visible (SALINERO et al., 2009).

The real fertility index of buds was obtained by dividing the number of shoots with inflorescences by the total number of buds of canes in each plant, left after pruning. This evaluation was carried out in November 2016, during the end of flowering. In addition, the number, percentage and position of non-sprouted buds, flowering buds without flowers (vegetative shoots) and flowering buds with inflorescences (mixed shoots) were determined. For this, four canes per plant were evaluated on November 29, 2016.

Leaf attributes were measured through the evaluation of area, dry mass and specific leaf area. Leaf 
area was determined by the use of a Li-Cor leaf area meter (LI-3100). Leaf dry mass (g) was determined on analytical balance after oven drying at $65^{\circ} \mathrm{C}$ with forced air circulation for 72 hours. Specific leaf area $\left(\mathrm{cm}^{2} \mathrm{~g}^{-1}\right)$ was determined from the division of the leaf area $\left(\mathrm{cm}^{2}\right)$ by dry mass (g). For these evaluations, six leaves per quadrant were randomly collected, totaling 24 leaves per sampled plant on February 7, 2017.

On February 13, 2017, the diameter and length of five vegetative shoots (without production) and five mixed shoots (with fruit production) per quadrant were measured, totaling 40 shoots (from canes) per plant. The diameter measurement was obtained with a digital caliper near the base of the shoot and length using tape measure.

Fruits were harvested on April 27, 2017. Plant yield $\left(\mathrm{kg} \mathrm{plant}^{-1}\right)$ and total number of fruits per plant were determined from the harvest and weighing of all evaluated fruits. Productivity $\left(\mathrm{kg} \mathrm{ha}^{-1}\right)$ was obtained from plant density per hectare and plant yield.

At the time of harvest, samples of 40 fruits were collected per replicate. The cross-sectional and longitudinal diameters of fruits were measured with the aid of a caliper, and the fresh fruit mass was measured by weighing in digital scale. Fruits were separated into four classes according to the mean weight (BRASIL, 1998): large (102 to $150 \mathrm{~g}$ ), medium ( 80 to $101 \mathrm{~g}$ ), small (63 to $79 \mathrm{~g}$ ) and very small (45 to $62 \mathrm{~g}$ ). After storage in cold chamber with constant temperature of $5^{\circ} \mathrm{C}$ for 10 days, evaluations were carried out for the physicochemical characterization of fruits. For flesh firmness measurement $(\mathrm{N})$, the skin was removed on two opposite sides of each sampled fruit, next to the cross-section plane and the measurement made with a bench penetrometer with 8 $\mathrm{mm}$ tip. Soluble solids content (SS) was performed with portable digital refractometer (Pocket PAL-1 model) and reading expressed in ${ }^{\circ} \mathrm{Brix}$. The $\mathrm{pH}$ was measured and the total titratable acidity (TTA) was determined by titrating a sample of diluted kiwi juice with $0.1 \mathrm{~N}$ sodium hydroxide until $\mathrm{pH} 8.1$ was reached, and the results expressed as \% citric acid. SS and TTA values were used to determine the SS/TTA ratio.

Treatments were submitted to analysis of variance by the F-test. When significant $(\mathrm{p}<0.05)$, their means were compared by the Tukey test. For the multivariate analysis, mean deviations were compared to each other by the t-test $(\mathrm{p}<0.05)$. The IBM SPSS statistical package version 22 (IBM Corporation, Armonk, NY, USA) was used.

\section{Results and discussion}

Pruning intensities did not influence the budbreak and flowering periods of kiwifruit trees, which occurred between September 7 and 20, and between October 21 and November 6, respectively. The year of 2016 was marked by a cold winter, with sum of $\mathrm{CH}$ below $7.2^{\circ} \mathrm{C}$ higher than the climatological standards for Farroupilha (MATZENAUER et al., 2005), favoring floral induction and differentiation of buds. According to Wall et al. (2008), the uniformity and floral density are directly related to the amount of cold received during the winter.

The mixed bud percentage was higher near the cane apex in the three different treatments (Figure 2A). The penultimate and last bud reached, respectively, mixed bud percentages of 77.78 and $91.67 \%$ in treatment with 10 buds; 78.13 and $100 \%$ in treatment with 15 buds, and 80.56 and $91.67 \%$ in treatment with 20 buds cane $^{-1}$. According to Antunes (2008), the apical zone of canes is the region where kiwifruit trees produce more fruits, corroborating data of our work. With respect to the mixed buds of the base of canes, the three treatments had the same behavior, that is, those located close to the base of canes in the three different load levels presented the lowest mixed shoots percentages, when compared with the other cane bud positions, within the same treatment. In the comparison of mixed buds among the different bud load levels, considering only the differences within the same position along the cane, treatments differed only in the apical buds.

In vines, Lebon et al. (2004) suggest that the development of each bud is affected by the plant's reserve level and by tropic competition among the various shoots. For Naor et al. (2003), the strong apical dominance in apple trees associated to the lower cold requirement of terminal buds masks the effects of cold on lateral buds, reducing their sprouting. The results of this work show that kiwifruit trees behave similarly to these cultures.

Austin et al. (2002) consider that, in kiwifruit tree, the effect of the bud position on sprouting is linked to two aspects: the "structural effect", which assumes the size variation and stage of development among buds; and the "neighbor effect", related to correlative interactions among buds of the same cane. The same authors suggest that the interactions among kiwifruit buds are polarized, so the loss of budbreak potential is a consequence of the influence of the neighboring bud located in the most distal position. Moreover, according to Taiz and Zeiger (2017), in most of "true woody plants", apical dominance is exerted through the production of auxins at the apex, which is transported in the basipetal direction, inhibiting sprouting and growth of buds located in previous positions.

The effect of treatments on the percentage of vegetative shoots was not significant (Figure 2B). Nonsprouted buds presented a pattern that was the opposite of mixed sprouted buds. At the base of canes, in the three different treatments, the highest percentage of nonsprouted buds occurred (Figure 2C). Austin et al. (2002) suggest that, in warmer regions, the sprouting delay due to lack of cold increases the loss of potential of basal buds, increasing the percentage of non-sprouted buds. 
Giorgio and Standardi (1991), in an experiment conducted in southern Italy with 'Hayward' cultivar conducted in trellis system, showed that the number of buds per cane affects significantly the vegetative and productive performance of plants. In addition, for the evaluated variables, differences between bud load per cane were greater than differences between years.

The percentage of total sprouting and nonsprouted buds did not differ among treatments (Table 1). However, the number of buds per cane was inversely proportional to the number of mixed shoots per plant (Table 1). The real fertility index of buds did not differ statistically among treatments, presenting average of $46 \%$ of sprouted buds with inflorescence per cane (Table 1). Inglese and Gullo (1992) also did not find significant differences in the percentage of total sprout and mixed sprouts, comparing 'Hayward' kiwifruit canes with 6, 12 and 18 buds. Vittone (2010) reported that in the Piedmont region, approximately $50 \%$ of sprouted buds are mixed. In New Zealand, the proportion of dormant buds that sprouted in the spring usually does not exceed $50 \%$, and may be up to $30 \%$ (MCPHERSON et al., 1994).

In the mean of 3 years, Giorgio and Standardi (1991) observed 47.8 and $41.8 \%$ of sprouting in canes with 12 and 18 buds, respectively. The same authors, under the conditions of southern Italy, found that the sprouting percentage decreased with the increase of buds per cane. However, they point out that in northern Italy, high sprouting percentages are reached with 6 buds per cane and therefore assume that these differences are linked to the plant's cold requirement, which in southern Italy may not be totally attended. It is clear that kiwifruit requires a period of low temperatures during dormancy to reach adequate flowering in the following spring (MCPHERSON et al., 2001); however, the factors controlling the onset of dormancy during autumn, the accumulation of cold in winter and end of dormancy in spring are still poorly studied (SNELGAR et al., 2007).

The development of kiwifruit flowers occurs in two growing seasons (WALTON et al., 2001). For Snelgar et al. (2007), one of the main physiological reasons that impede the increase in the percentage of fertile buds is the relatively long period between floral evocation and floral differentiation, which can make kiwifruit trees more susceptible to floral reversal or abortion. Moreover, for Snelgar and Manson (1992), floral evocation seems to occur progressively from base to the apex of each budding in the period near the end of leaf expansion.

Regarding leaf attributes, significant differences among treatments were observed for leaf area per leaf and leaf dry matter (Table 1). The specific leaf area remained unchanged in the different treatments. The decrease in bud load per cane induced an increase in leaf size and, consequently, an increase in leaf dry matter. These results may be related to the fact that, since they did not cause an increase in sprouting percentage, treatments with lower bud load had larger area for growth and/or higher source/ sink relationship.

According to Foster et al. (2007), kiwifruit shoots are morphologically distinct between expanding and nonexpanding, that is, shoots continue to grow during the cycle and can exceed 2 meters in length, and shoots can have determined growth. The definition of the shoot type depends on the number of phytomers (multiple repetitions formed by leaf, axillary meristem, node and internode) preformed in the bud, of new phytomers initiated in the apical meristem during shoot growth and also the growth paralysis, which results from the abortion of the apical shoot meristem. Low temperatures during the onset of shoots growth result in an increased likelihood of meristem abortion.

Between September and October 2016, when shoots were beginning to grow, $70 \mathrm{CH}$ below $7.2{ }^{\circ} \mathrm{C}$ occurred in the experimental area, which probably caused an increase in the number of non-expansive shoots, since the average length of year branches was $26.7 \mathrm{~cm}$ (Figure 3). Treatments also affected the length and diameter of branches. Plants pruned with 10 buds per cane presented the highest lengths and diameters of mixed and vegetative shoots. For these evaluations, plants with 15 and 20 buds per cane did not differ significantly from each other (Figure 3).

In a study carried out with 'Hayward' cultivar in northern Italy, Giorgio and Standardi (1991) evaluated canes with 6,12 and 18 buds and found average shoot length between 172 and $199 \mathrm{~cm}$ at the end of the growing season. The fresh weight of pruning decreased from 19.1 to $13.3 \mathrm{~kg} \mathrm{plant}^{-1}$, as the number of buds per cane increased from 6 to 18 and longer shoots were the result of canes with 12 buds.

In the present study, the longitudinal and cross-sectional diameter, and fruit mass were inversely proportional to the number of buds per cane (Table 2). According to Agustí (2010), the development and final size of fruits depend on their growth capacity, which is defined by the availability of plant metabolites, which explains the results found. In addition, plants pruned with 10 buds per cane had 38.9 and $58.3 \%$ of fruits considered large and medium, respectively (Figure 4). It is important to note that no thinning was performed this year but still, $97.2 \%$ of fruits of treatment with 10 buds cane $^{-1}$ were within large and medium classes, which receive higher commercial values. Green pruning that stimulates regrowth in the first 100 days after flowering may have a very negative impact on fresh mass and dry mass of fruits at harvest due to competition for photoassimilates (MINCHIN et al., 2010). As there was no need for green pruning during the experiment, the increase in the carbohydrate source in treatment with 10 buds resulted in higher fruit growth. 
Treatments of 15 and 20 buds per cane did not present large fruits. The distribution of medium, small and very small fruits in treatment with 15 buds was $62.5 \%$, $34.4 \%$ and $3.1 \%$, respectively. In pruned plants with 20 buds, the percentage of fruits per class varied from $40.6 \%$, $50.0 \%$ and $9.4 \%$, for medium, small and very small, respectively (Figure 4). These data corroborate results of Giorgio and Standardi (1991), who observed a reduction in fresh fruit mass of 'Hayward' cultivar, from 92.9 to $81.5 \mathrm{~g}$ with increase from 6 to 18 buds per cane. Testolin (1990) indicates that the average mass of 'Hayward' fruits decreases $0.08 \mathrm{~g}$ for each increase of $1000 \mathrm{buds} / \mathrm{ha}$. Cangi and Atalay (2006) did not observe variation in fresh mass of 'Hayward' fruits in treatments that maintained from 180 to 300 buds per plant, presenting mean of $121.8 \mathrm{~g}$ per fruit. Only treatment with 120 buds per plant presented heavier fruits when compared to the other treatments proposed by the authors. Famiani et al. (1997) indicate that in Actinidia deliciosa, 2 to 4 leaves exposed to the sun per fruit are necessary to guarantee normal fruit development and quality. Minchin et al. (2010) showed that, at harvest, 'Hayward' fruit supplied with 7 leaves has greater fresh and dry mass than fruit supplied with 4 leaves.

When the ratio between the largest and the smallest cross-sectional diameter of fruits is less than 0.8 , it is considered flat (BRASIL, 1998). Flat fruit is one of the items defined as a defect for commercialization, which reduces the commercial value of fruits. In the present study, the different bud load levels did not change the value of this variable, which was 0.9 in all treatments (Table 2).

In treatment with 20 buds per cane, an increase in the number of fruits per plant was observed, when compared to treatment with 10 buds (Table 2). However, production per plant and yield did not differ statistically among the three treatments. The average yield of the three treatments was $27.2 \mathrm{t} \mathrm{ha}^{-1}$, much higher than the Farroupilha average in trellis system, which is $15.1 \mathrm{t}$ ha $^{-1}$ (SILVEIRA et al., 2015). The lack of difference in productivity in the treatments proposed in our study may be related to the fact that, in treatment with 20 buds per cane, the number and size of leaves were insufficient to meet the carbohydrate demand of fruits. As the fruit mass had an inverse behavior to the increase of the bud load per cane, the final yield remained the same in the different treatments. Costa et al. (1990) distributed 220 buds along 11 canes (long pruning) and 22 canes (short pruning) per plant and did not find significant differences in the percentage of total sprouting, mixed shoots and productivity, in the comparison between long and short pruning.

Regarding the physicochemical characteristics, it was observed that, in plants pruned with 15 buds per cane, $\mathrm{pH}$, soluble solids content and the SS/TTA ratio were lower than in the other treatments. Firmness and total titratable acidity remained higher in treatment with
15 buds per cane, when compared to the other treatments (Table 3). It should be noted that, even presenting statistical differences, TTA ranged from 1.5 to $1.8 \%$ among treatments, without influencing the organoleptic properties of fruits. In Turkey, Gökbayrak et al. (2012) found lower soluble solids content in 'Hayward' fruits harvested from plants with 16 buds per cane when compared to pruning levels of 4 and 8 buds; however, $\mathrm{pH}$ and TTA did not differ among treatments in the Turkish work. In the work proposed by Cangi and Atalay (2006), with increasing bud load per plant, the soluble solids content decreased in fruits.

The continuous supply of soluble carbohydrates to fruits depends on the photosynthetic activity of leaves. Soluble carbohydrates are converted into starch and subsequently degraded into soluble solids (BURDON et al., 2016). In the present study, the variation coefficient among treatments in soluble solids was $14.5 \%$. At the point of consumption, kiwifruits should reach $12^{\circ}$ Brix (BRASIL, 1998). Fruits of treatment with 10 buds showed average of $12.4{ }^{\circ}$ Brix after the storage period, being statistically superior to the other treatments. Fruits harvested with the same SS concentration may differ physiologically, resulting from starch metabolism, interfering with post-harvest fruit performance (BURDON et al., 2016). Other studies related to kiwifruit tree are necessary for the improvement of the cultural management of the plant in the edaphoclimatic conditions of Brazil. 


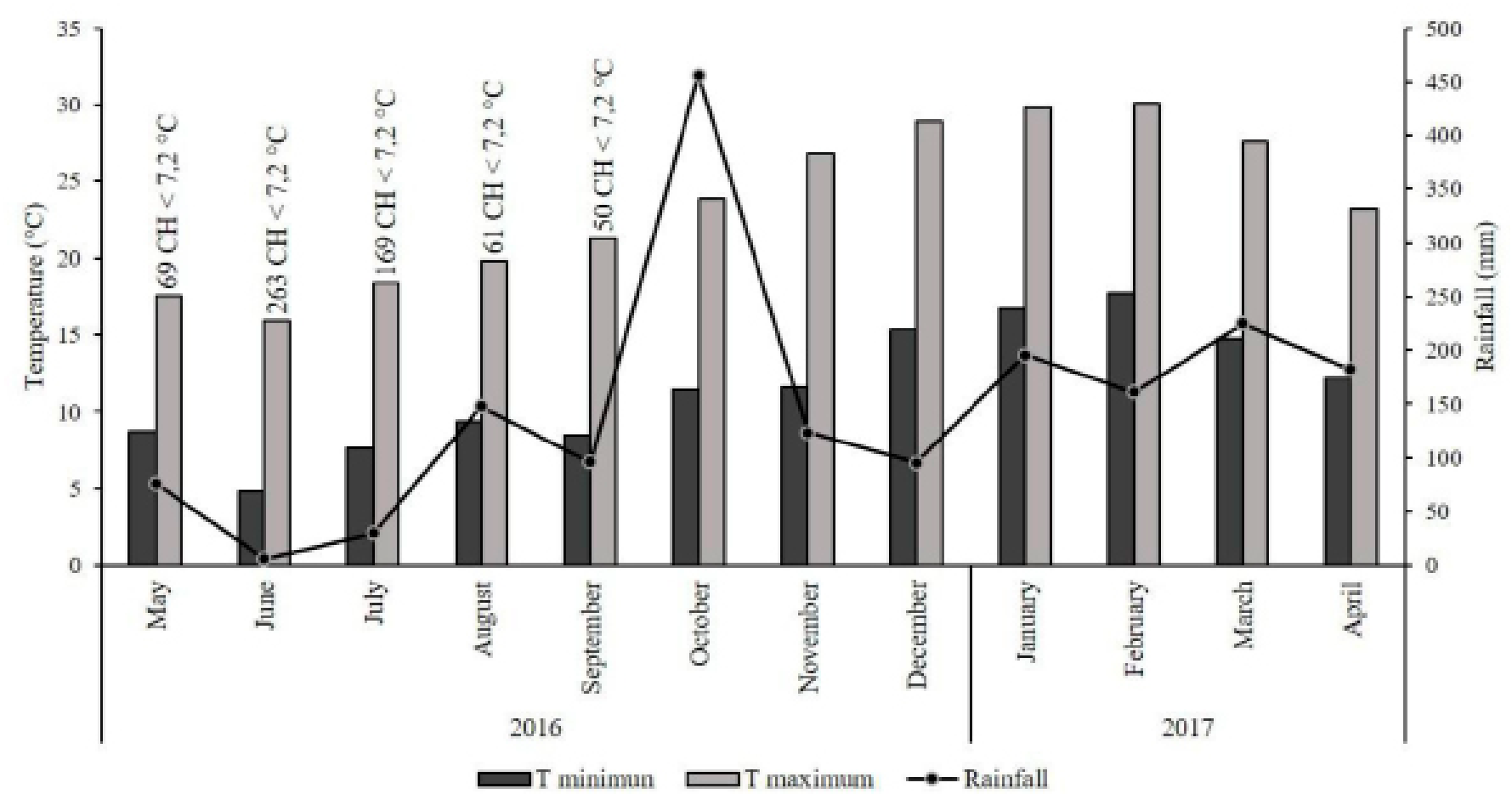

Figure 1. Sum of rainfall precipitation, monthly average of minimum and maximum air temperatures between may 2016 and april 2017 in the experimental area, municipality of Farroupilha-RS $\left(29^{\circ} 08^{\prime} 58.6^{\prime \prime} \mathrm{S}\right.$ and $51^{\circ} 24^{\prime} 46.8^{\prime \prime} \mathrm{W}$, $708 \mathrm{~m}$ above sea level). Monthly cold hours (CH) below 7,2 ${ }^{\circ} \mathrm{C}$ between may 2016 and april 2017 are indicated inside the figure.

Table 1. Total sprouting (TS), non-sprouting buds (NSB), number of mixed shoots per plant (nMS), real fertility index (RFI), leaf area per leaf(LA), leaf dry mass (LDM) and specific leaf area (SLA) of 'Elmwood' kiwifruits trees submitted to pruning with differen bud load levels on each cane $(10,15,20)$ during 2016/2017 cycle, in Farroupilha-RS ${ }^{(1)}$.

\begin{tabular}{cccccccc}
\hline Bud load levels & $\begin{array}{c}\text { TS } \\
(\%)\end{array}$ & $\begin{array}{c}\text { NSB } \\
(\%)\end{array}$ & nMS & RFI & $\begin{array}{c}\text { LA } \\
\left(\mathrm{cm}^{2}\right)\end{array}$ & $\begin{array}{c}\text { LDM } \\
(\mathrm{g})\end{array}$ & $\begin{array}{c}\text { SLA } \\
\left(\mathrm{cm}^{2} \mathrm{~g}\right)\end{array}$ \\
\hline 10 & $70,6^{\text {ns }}$ & $29,4^{\text {ns }}$ & $55,5 \mathrm{c}$ & $0,48^{\text {ns }}$ & $106,0 \mathrm{a}$ & $1,08 \mathrm{a}$ & $99,0^{\text {ns }}$ \\
15 & 74,0 & 26,0 & $81,0 \mathrm{~b}$ & 0,45 & $92,8 \mathrm{~b}$ & $0,97 \mathrm{ab}$ & 96,2 \\
20 & 68,9 & 30,7 & $109,0 \mathrm{a}$ & 0,45 & $82,7 \mathrm{c}$ & $0,90 \mathrm{~b}$ & 93,0 \\
\hline Average & 71,2 & 28,7 & 81,8 & 0,46 & 93,8 & 0,98 & 96,1 \\
CV $(\%)$ & 19,9 & 48,4 & 44,0 & 33,2 & 22,1 & 24,3 & 13,6 \\
\hline
\end{tabular}

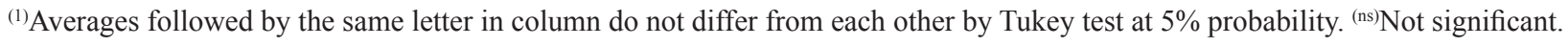

Table 2. Longitudinal diameter (LD), smaller cross-sectional diameter (SCD), larger cross-sectional diameter (LCD), $\mathrm{SCD} / \mathrm{BCD}$ ratio, number of fruits per plant, fruit weight, plant yield and productivity of 'Elmwood' kiwifruits trees submitted to pruning with differen bud load levels on each cane $(10,15,20)$ during 2016/2017 cycle, in Farroupilha$\mathrm{RS}^{(1)}$.

\begin{tabular}{ccccccccc}
\hline $\begin{array}{c}\text { Bud load } \\
\text { levels }\end{array}$ & $\begin{array}{c}\text { LD } \\
(\mathrm{cm})\end{array}$ & $\begin{array}{c}\text { SCD } \\
(\mathrm{cm})\end{array}$ & $\begin{array}{c}\text { LCD } \\
(\mathrm{cm})\end{array}$ & $\begin{array}{c}\text { SCD/ } \\
\text { LCD }\end{array}$ & $\begin{array}{c}\text { Number of fruits } \\
\text { per plant }\end{array}$ & $\begin{array}{c}\text { Fruit weight } \\
(\mathrm{g})\end{array}$ & $\begin{array}{c}\text { Plant yield } \\
\left(\mathrm{kg} \mathrm{planta}^{-1}\right)\end{array}$ & $\begin{array}{c}\text { Productivity } \\
\left(\mathrm{kg} \mathrm{ha}^{-1}\right)\end{array}$ \\
\hline 10 & $65,7 \mathrm{a}$ & $46,6 \mathrm{a}$ & $51,1 \mathrm{a}$ & $0,9^{\text {ns }}$ & $225,9 \mathrm{~b}$ & $99,6 \mathrm{a}$ & $24,9^{\text {ns }}$ & $24.919,4^{\text {ns }}$ \\
15 & $59,6 \mathrm{~b}$ & $44,4 \mathrm{~b}$ & $49,0 \mathrm{~b}$ & 0,9 & $316,7 \mathrm{ab}$ & $81,5 \mathrm{~b}$ & 27,4 & $27.370,5$ \\
20 & $56,2 \mathrm{c}$ & $42,8 \mathrm{c}$ & $47,0 \mathrm{c}$ & 0,9 & $359,0 \mathrm{a}$ & $73,5 \mathrm{c}$ & 29,4 & $29.373,6$ \\
\hline Average & 60,5 & 44,6 & 49,0 & 0,9 & 306,7 & 84,7 & 27,2 & $27.221,2$ \\
CV $(\%)$ & 8,8 & 5,7 & 6,0 & 2,4 & 36,7 & 19,5 & 28,2 & 28,2 \\
\hline
\end{tabular}

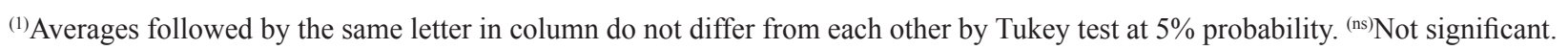



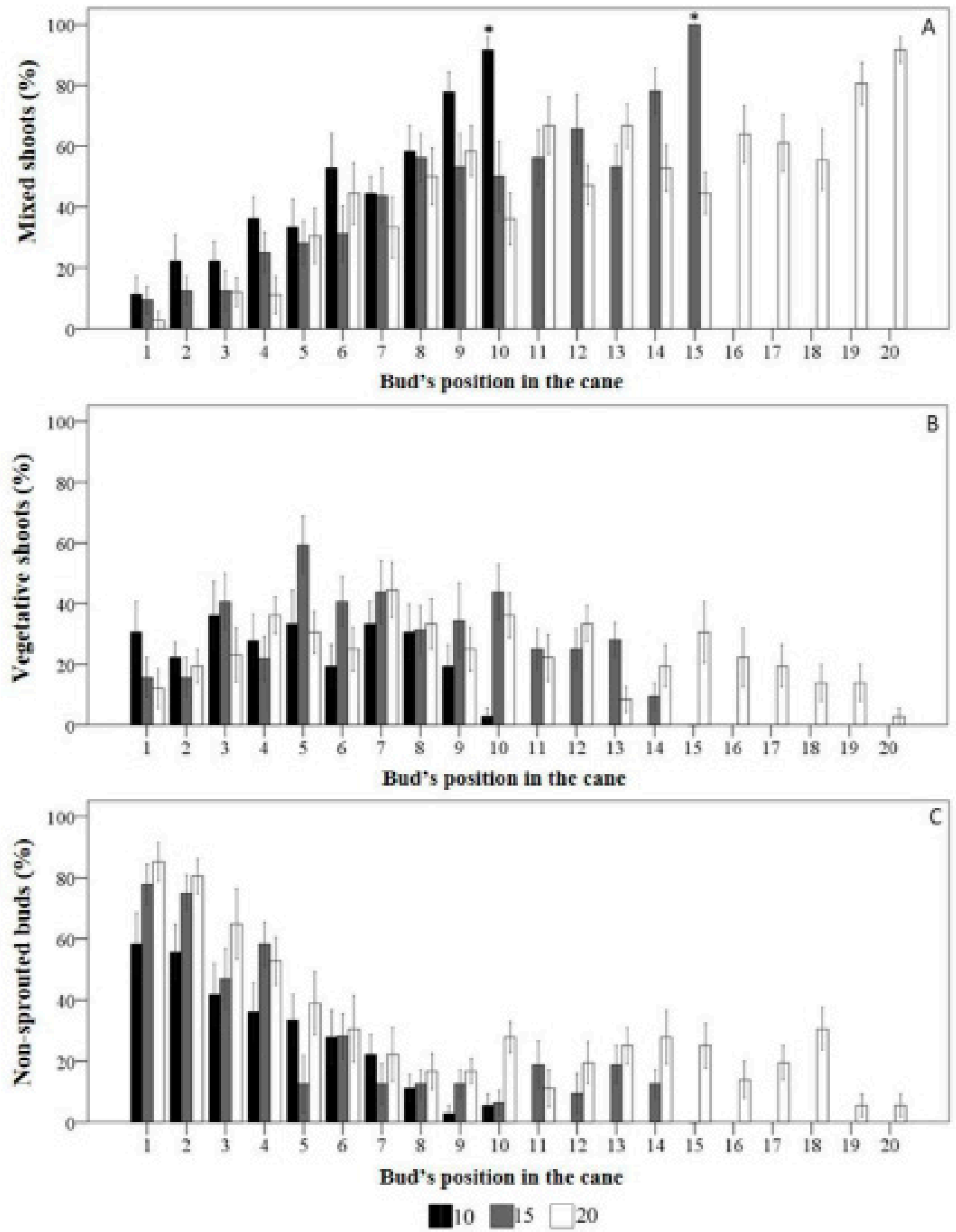

Figure 2. Percentage of mixed shoots (A), vegetative shoots (B) and non-sprouted buds (C) per position (starting in the base to the apix) along the canes of 'Elmwood' kiwifruits trees submitted to pruning with differen bud load levels on each cane $(10,15,20)$ during 2016/2017 cycle, in Farroupilha-RS. Vertical bars represent the standard error of the mean. *Significant difference between means of two treatments by $\mathrm{t}$-test $(\mathrm{p}<0.05)$. 

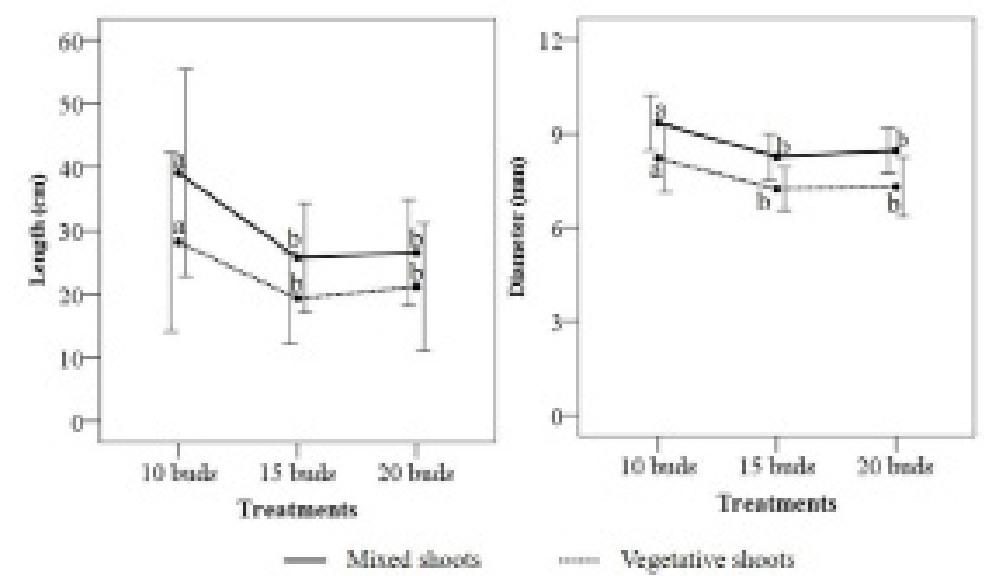

Figure 3. Lenght and diameter of mixed and vegetative shoots of 'Elmwood' kiwifruits trees submitted to pruning with differen bud load levels on each cane $(10,15,20)$ during 2016/2017 cycle, in Farroupilha-RS. Averages followed by the same letter do not differ from each other to a same analyzed variable in the different treatments by Tukey test at $5 \%$ probability. Vertical bars represent the standard deviation of the means.

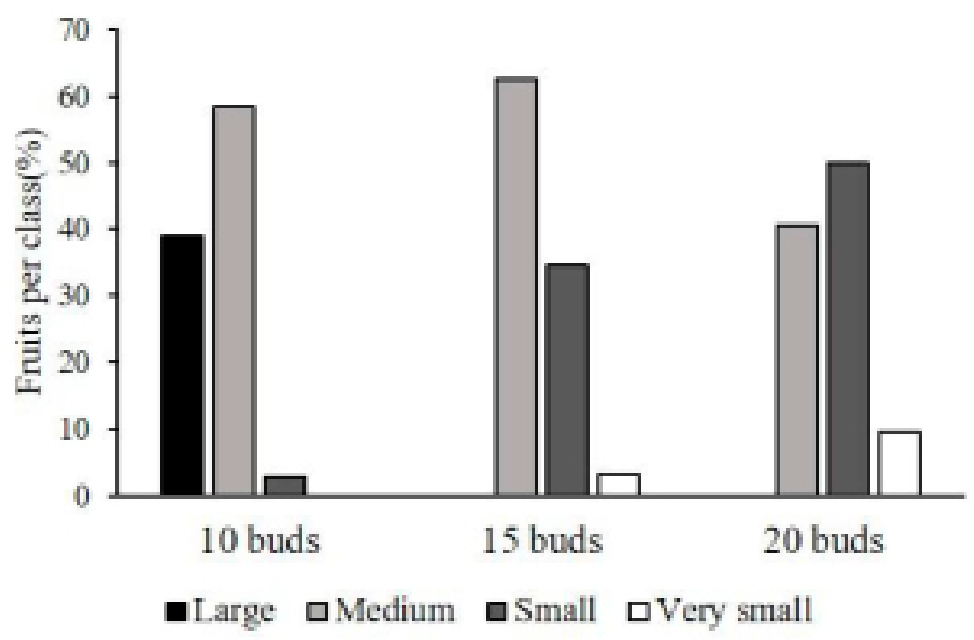

Figure 4. Percentage of fruits from 'Elmwood' kiwifruits trees separated into four classes according to the weight: large (102 to $150 \mathrm{~g}$ ), medium ( 80 to $101 \mathrm{~g}$ ), small (63 to $79 \mathrm{~g}$ ) and very small (45 to $62 \mathrm{~g}$ ) submitted to pruning with differen bud load levels on each cane $(10,15,20)$ during 2016/2017 cycle, in Farroupilha-RS.

Table 3. Flesh firmness, $\mathrm{pH}$, soluble solids content (SS), total titratable acidity (TTA), SS/TTA ratio fruits from 'Elmwood' kiwifruits trees submitted to pruning with differen bud load levels on each cane $(10,15,20)$ during 2016/2017 cycle, in Farroupilha-RS ${ }^{(1)}$.

\begin{tabular}{cccccc}
\hline $\begin{array}{c}\text { Bud load } \\
\text { levels }\end{array}$ & $\begin{array}{c}\text { Firmness } \\
(\mathrm{N})\end{array}$ & $\mathrm{pH}$ & $\begin{array}{c}\mathrm{SS} \\
\left({ }^{\circ} \mathrm{Bx}\right)\end{array}$ & $\begin{array}{c}\text { TTA } \\
(\%)\end{array}$ & SS/TTA \\
\hline 10 & $3,9 \mathrm{~b}$ & $3,4 \mathrm{a}$ & $12,4 \mathrm{a}$ & $1,6 \mathrm{~b}$ & $7,6 \mathrm{a}$ \\
15 & $8,3 \mathrm{a}$ & $3,3 \mathrm{~b}$ & $10,6 \mathrm{c}$ & $1,8 \mathrm{a}$ & $5,9 \mathrm{~b}$ \\
20 & $2,9 \mathrm{~b}$ & $3,4 \mathrm{a}$ & $11,4 \mathrm{~b}$ & $1,5 \mathrm{c}$ & $7,5 \mathrm{a}$ \\
\hline Average & 5,0 & 3,4 & 11,1 & 1,6 & 7,0 \\
CV $(\%)$ & 67,5 & 2,0 & 14,1 & 10,2 & 15,7 \\
\hline
\end{tabular}

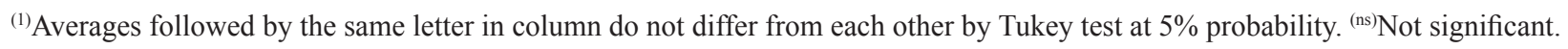




\section{Conclusions}

The pruning of 'Elmwood' kiwifruit trees with different bud loads does not influence the real fertility index of buds, but cane bud load interferes directly in the size of leaves and shoots;

Pruning maintaining canes with 10 buds favors the increase of fruit mass and does not reduce productivity;

In 'Elmwood' kiwifruit, the highest proportion of mixed buds is close to the apex and the highest proportion of non-sprouted buds is located at the base of canes

\section{References}

AGUSTÍ, M. Fruticultura. Madrid: Mundi-Prensa, 2010. $507 \mathrm{p}$.

ANTUNES, M. D. Kiwi. Da produção à comercialização. Algarve: Ciência da Terra Universidade do Algarve, 2008. $211 \mathrm{p}$.

AUSTIN, P.T.; HALL, A.J.; SNELGAR, W.P.; CURRIE, M.J. Modelling kiwifruit budbreak as a function of temperature and bud interactions. Annals of Botany, Oxford, v.89, n.6, p.695-706, 2002.

BRASIL. Ministério da Agricultura, Pecuária e Abastecimento. Portaria n ${ }^{\circ}$ 34, de 16 de janeiro de 1998. Norma de identidade, qualidade, acondicionamento, embalagem e apresentação do kiwi. Diário Oficial da União, Brasília, DF, 19 jan. 1998.

BRASIL. Ministério de Desenvolvimento, Indústria e Comércio Exterior. Balança comercial brasileira. 2017. Disponível em: $<$ http://aliceweb.mdic.gov.br//consultancm/consultar>. Acesso em: 25 dez. 2017.

BURDON, J.; PIDAKALA, P.; MARTIN, P.; BILLING, D.; BOLDINGH, H. Fruit maturation and the soluble solids harvest index for "Hayward" kiwifruit. Scientia Horticulturae, New York, v.213, p.193-198, 2016.

CACIOPPO, O. L'actinidia. Roma: Reda, 1989. 189p.

CANGI, R.; ATALAY, D.A. Effects of different bud loading levels on the yield, leaf and fruit characteristics of Hayward kiwifruit. HortScience, Alexandria, v.33, p.23-28, 2006.

COSTA, G; SUCCI, F; BIASI, R; MISEROCCHI, O. Vegetative and cropping performance of kiwifruit as related to pruning lenght and bud load. Acta Horticulturae, The Hague, v.282, p.113-118, 1990.
FAMIANI, A; ANTOGNOZZI, E; BOCO, M; TOMBESI, A; BATTISTELLI, SPACCINO, L. Effects of altered source-sink relations on development and quality of kiwi. Acta Horticulturae, The Hague, v.1, p.355-360, 1997.

FAO - Food and Agriculture Organization of the United Nations Statistics Division. Food and agricultural commodities production/Countries by commodity. Rome, 2017. Disponível em: <http://www.fao.org/faostat/ en/?\#data/QC>. Acesso em: 25 dez. 2017.

FOSTER, T.M.; SELEZNYOVA, A.N.; BARNETT, A.M. Independent control of organogenesis and shoot tip abortion are key factors to developmental plasticity in kiwifruit (Actinidia). Annals of Botany, Oxford, v.100, n.3, p.471-481, 2007.

GÖKBAYRAK, Z.; ENGIN, H.; DARDENIZ, A. Can pruning be utilized to minimize aberrant fruit formation in kiwifruit? Sci YYUJAGR, v.22, n.2, p.113-116, 2012 .

INGLESE P.; GULLO G. Influence of pruning length and bud load on plant fertility, yield and fruit characteristics of "Hayward" kiwifruit. Acta Horticulturae, The Hague, v.297, p.451-458, 1992.

GIORGIO, V.; STANDARDI, AL. Vegetative and reproductive behaviour of kiwifruit as related to cane length. New Zealand Journal of Crop and Horticultural Science, Wellington, v.19, n.4, p.349-353, 1991. Disponível em: <http://www.tandfonline.com/doi/abs/1 0.1080/01140671.1991.10422874>. Acesso em: $12 \mathrm{dez}$. 2017.

INMET. Normais climatológicas - Gráficos Climatológicos de 1961-1990. 2018. Disponível em: $<$ http://www.inmet.gov.br/portal/index.php? $\mathrm{r}=\mathrm{clima} /$ graficosClimaticos>. Acesso em: 06 nov. 2017.

LEBON, E.; PELlEGRINO, A.; TARDIEU, F.; LECOEUR, J. Shoot development in grapevine (Vitis vinifera) is affected by the modular branching pattern of the stem and intra- and inter-shoot trophic competition. Annals of Botany, Oxford,, v.93, n.3, p.263-274, 2004.

MATZENAUER, R.; BUENO, A.C.; FILHO, A.C.; DIDONÉ, I.A., MALUF, J.R.T.; HOFMAN, G.; TRINDADE, J.K.; STOLZ, A.; SAWASATO, J.T.; VIANA, D.R. Horas de frio no Estado do Rio Grande do Sul. Pesquisa Agropecuária Gaúcha, Porto Alegre, v.11, n.1-2, p.71-76, 2005. Disponível em: <http://www. fepagro.rs.gov.br/upload/1398796957_art09.pdf $>$. Acesso em: 07 mai. 2017. 
MCPHERSON, H.G.; HALL, A.J.; STANLEY, C.J. Seasonal and regional variation in budbreak and flowering of kiwifruit vines in new zealand. New Zealand Journal of Crop and Horticultural Science, Wellington, v.22, n.3, p.264-276, 1994.

MCPHERSON, H.G.; RICHARDSON, A.C.; SNELGAR, W.P.; CURRIE, M.B. Effects of hydrogen cyanamide on budbreak and flowering in kiwifruit (Actinidia deliciosa "Hayward"). New Zealand Journal of Crop and Horticultural Science, Wellington, v.29, n.4, p.277-285, 2001.

MINCHIN, P.E.H.; SNELGAR, W.P.; BLATTMANN, P.; HALL, A.J. Competition between fruit and vegetative growth in Hayward kiwifruit. New Zealand Journal of Crop and Horticultural Science, Wellington,v.38, n.2, p.101-112, 2010.

NAOR, A.; FLAISHMAN, M.; STERN, R.; MOSHE, A.; EREZ, A. Temperature effects on dormancy completion of vegetative buds in apple. Journal of American Society for Horticultural Science, Alexandria, v.128, n.5, p.636-641, 2003.

SALINERO, M.C.; VELA, P.; SAINZ, M.J. Phenological growth stages of kiwifruit (Actinidia deliciosa "Hayward"). Scientia Horticulturae, Amsterdam, v.121, n.1, p.27-31, 2009.

SILVEIRA, S.V. da; GARRIDO, L. da R.; GAVA, R.;; SANTOS, R.S.S.dos; GIRARDI, C.L.; NICKEL, O.; LAZZAROTTO, J.J.; FIORAVANÇO, J.C. Diagnóstico do sistema de produção do quivi em pomares de Farroupilha/RS: principais demandas. Bento Gonçalves: Embrapa Uva e Vinho, 2015. 49 p. (Documentos, 93).

SNELGAR, W.P.; CLEARWATER, M.J.; WALTON, E.F. Flowering of kiwifruit (Actinidia deliciosa) is reduced by long photoperiods. New Zealand Journal of Crop and Horticultural Science, Wellington, v.35, n.1, p.33-38, 2007.
SNELGAR, W.P.; MANSON, P.J. Determination of the time of flower evocation in kiwifruit vines. New Zealand Journal of Crop and Horticultural Science, Wellington, v.20, n.4, p.439-447, 1992.

TAIZ, L.; ZEIGER, E. Fisiologia vegetal. 5. ed. Porto Alegre: Artmed, 2017. 918p.

TESTOLIN, R. Kiwifruit yield efficiency, plant density, and bud number per surface unit. Journal of American Society of Horticultural Science, Alexandria, v. 5 , n.115, p.704-707, 1990.

VITTONE, G. La qualità inizia dalla potatura : tecniche e suggerimenti per 1 ' actinidia. Frutticoltura, Bologna, p.64-66, 2010.

WALL, C.; DOZIER, W.; EBEL, R.C.; WILKINS, B.; WOODS, F.; FOSHEE, W. Vegetative and floral chilling requirements of four new kiwi cultivars of Actinidia chinensis and A. deliciosa. HortScience, Alexandria, v.43, n.3, p.644-647, 2008.

WALTON, E. F.; PODIVINSKY, E.; WU, R. M. Bimodal patterns of floral gene expression over the two seasons that kiwifruit flowers develop. Physiologia Plantarum, Copenhagem, v.11, n.3, p.396-404, 2001.

WILSON, G.J.; LITTLER, R.A. Kiwifruit shoot growth and yield as influenced by budbreak priority and cane bud position. Acta Horticulturae, The Hague, v.297, p.305-306, 1992.

ZHEN, Y.; LI, Z.; HUANG, H.; WANG, Y. Molecular Characterization of Kiwifruit (Actinidia) Cultivars and Selections Using SSR Markers. Journal of American Society of Horticultural Science, Alexandria, v.129, n.1293, p.374-382, 2004. 